\title{
Challenges of Offering Peace Education among Educational Leaders: A Case Study of Malaysian Public Primary School
}

\author{
Ahmad Zulfadhli Khairuddin ${ }^{1}$ \\ International Islamic University Malaysia \\ Afareez Abd Razak \\ International Islamic University Malaysia \\ Faizah Idrus \\ International Islamic University Malaysia \\ Nik Ahmad Hisham Ismail \\ International Islamic University Malaysia
}

\begin{abstract}
This paper explores the challenges of offering peace education in public primary school in Malaysia. In exact, this study: first, investigates how school educational leaders perceive peace education and how peace education could be included in the school curriculum. This study has adopted a qualitative design, employing semi-structured interview as an instrument of data collection. Findings suggest that all respondents reported that they mutually agreed to include peace education as part of the curriculum to maintain harmony, inculcate tolerance among students, minimize conflicts and know their country's history. Obstacles and challenges in introducing peace education as a subject in the school's curricular can be minimized to implementation of costs and teacher training. Lack of expertise and lack of interests among students are identified as another challenge in introducing peace education. Furthermore, school educational leaders were found to have low levels of awareness, knowledge, and skills related to peace education.
\end{abstract}

KEYWORDS: Peace Education, Social Studies, Qualitative Research, Educational Administration, Malaysia

\section{Introduction}

In recent years, there are numerous reports on act of terrorism across the globe as well as rising cases in the Malaysian soil (El-Muhammady, 2018; Mustafa, 2017; Zolkepli \& Tan, 2018). Many conflicts and wars have occurred that costed billions of innocent lives regardless of race, ethnicity and religious backgrounds. The word 'peace' seems to be a more rhetoric rather than a realistic means that can be achieved in this modern world. Peace means the absence of war. Peace also is the antonym of war or conflict. However to realize peace requires work that integrate many aspects of human life. UNESCO (2014) has stated that "War begin in the minds of men, it is in the minds of men that the defences of peace must be constructed". For

\footnotetext{
${ }^{1}$ Corresponding author; Ahmad Zulfadhli Khairuddin is completing his PhD in Social Foundation of Education at IIUM. E-mail: zulfadhlikhair@gmail.com
} 
that reason, United Nation came out with the concept of culture of Peace and declared in its resolution 53/243, under Article 1, on the definition of culture of peace: "It is not only is the absence of conflict, but also requires a positive, dynamic participatory process where dialogues are encouraged and conflicts are solved in a spirit of mutual understanding and cooperation" (UN General Assembly, 1999). In the same resolution they developed the concept of culture of peace further and stated that it could be achieved through its crucial components such as respecting a set of values, attitudes, traditions, ending of violence and practice of non-violence through education, dialogue and cooperation (UN General Assembly, 1999).

In realizing this mission, Peace Education can be one of the means to educate younger generation about the importance of peace and how it affects ones country to maintain its stability and harmonious environment given the challenges today faced by them where globalization, terrorism and war on ideologies spread out more rampantly (Abd Kadir, Haneem, \& Ismail, 2014; Khairi, 2016; Miller, 2018; Samuel, 2018; Shamsul \& Anis, 2011).

In other highly developed countries such as Sweden, Germany, Canada, the United States, and the Netherlands, Peace Education is not a new term and it has been discussed broadly in their curriculum development (Demir, 2011). In Malaysia be it in primary, secondary or even at preschool level (Abd Kadir et al., 2014), Peace Education is almost alien for school goers, even to some teachers. Nevertheless, Malaysia is a multiracial country with diverse cultural and religious beliefs which is in dire need to maintain her peace and harmony. Unfortunately, in the recent years, there had been a strong unhealthy rift between ethnic groups. According to Shamsul and Anis (2011) there is a worrying state of ongoing unstable relationship between ethnic groups in Malaysia. In 1969, there was an ethnic clash that emerged from Malay and Chinese group conflicts that resulted in a bloody battle (Shamsul \& Anis, 2011). After this incident, many policies and monitoring bodies were established to gauge the tension between inter-racial groups and ethnicity in Malaysia, mentioned by Shamsul and Anis (2011):

The New Economic Policy (NEP) was introduced, in 1971, to address, in short and long-term, the intra and interethnic socio-economic differences resulting from the complex diversities in the country - ethnic, cultural, religious, regional, political orientation and economic activity. The Rukun Negara (National Charter) was created as an ideology to be embraced by Malaysians from all walks of life. A Department of National Unity was established as a bureaucratic instrument to keep watch over the state of ethnic relations in Malaysia. (p. 6)

However, hitherto there is not much improvement on the relationship between interracial groups especially between three dominant races namely Malay, Chinese and Indian. To understand this complexity, we must first understand the nature of an ethnic group that can be further categorized into classification of majority and minority that exist in Malaysia. The Chinese and the Malays are the two major ethnic groups in Malaysia. The Chinese are considered the majority non-bumiputra group whereas Malays are the majority bumiputra group. Bumiputra means the actual citizen or the land owner of a country particularly in the context of Malaysia. If the clashes between these two major groups could be settled, then there will be no ethnic problems in this country (Osman, 2013; Raza, 2018). This is because to understand the nature of the minority group four aims were suggested by Simpson (n.d.) (as cited in Osman, 2013) namely pluralistic, assimilation, secessionist and militancy. These four aims were manifested to ensure minority group be accepted in the society. Pluralistic means a minority ethnic group desiring to live peacefully side by side with the majority and other minorities. Assimilation means the minority wanted to be assimilated into other dominant culture. Thirdly, when these two processes are not achieved then the minority will develop a secessionist movement dedicated to complete independence and finally if all effort is not achieved, military struggle is the final resort to fight for independence (Osman, 2013). In addition, while the Malays remain as the dominant group that does not permit any changes, it 
is can be observed that some Malays are seen as not to welcome assimilation from small minority group as they fear that if no distinction is placed between ethnic groups, the Malays will lose the privilege as stated in the constitution.

\section{Literature Review}

Literature of peace has witnessed a major improvement from the theory of peace into more scientific discipline. In the $60 \mathrm{~s}$, peace discipline has been developed by pioneer Johan Galtung where he discussed about the fundamentals of positive and negative peace. The definition and concept of peace does not necessarily mean the absence of war per se rather it involves a wider concept that requires every individuals and segment of society to aspire its realisation. Demir (2011) in his study revealed that the concept of peace as a setting where harmony, mutual understanding and tolerance rule. Whereas Brion-Meisels and Brion-Meisels (2012) in their study included peace definition as not only a mere concept of no war rather they included the most important aspect in creating, maintaining and sustaining peace-making effort namely culture or peace culture. They stated that peace-making concepts and values are consistent across cultures and it can serve as an important foundation to materialize social justice.

\section{Peace Definition}

Peace and peace-making can only be achieved through mutual understanding, across cultural barriers and must include in the work of education (Brion-Meisels \& Brion-Meisels, 2012; Brock-Utne, 2009; Demir, 2011). To educate for peace can only be obtained through the means of education before the conflict emerges as after the conflict or war has erupted peace process can be very difficult and almost impossible (El-Muhammady, 2016).

\section{Concept of Peace Education}

Thus, peace education is undoubtedly important to be included in any modern educational system (Cabedo-Mas, 2015; Demir, 2011; El-Muhammady, 2018; Lamanauskas, 2015; Samuel, 2018), where peace education can be seen being implemented and is starting to get into the eyes of the policy makers as one of the precursor in ensuring a country's stability and wellness especially when it involves any multicultural/multi society with different aspects of background and level of education (Oueijan \& Tannous, 2011; Lafer \& Tarman, 2019; Tarman \&Kilinc, 2018).

Previously in Malaysia, the Malaysian education system in the 70's, introduced a syllabus called Tata Rakyat or Civic Conduct that focused on the relationship between citizens of Malaysia of multi-ethnic and multi-religious background. It was written in three books and with many chapters that included how a nation should interact with other countries internationally and locally. This included a lesson in understanding how a United Nation works' influenced the citizens and how they should act accordingly when a disaster strikes us (Khairi, 2016; Mustafa, 2017). Unfortunately, to date, the Ministry of Education no longer continues the subject in the current curriculum. It is being replaced by moral education for non-Muslims students and Islamic education for Muslim students (Ministry of Education, 2013). This creates a non-lineal understanding in peace-making effort in creating a harmonious society. According to some previous studies, education of peace should be carried out cross culturally and unanimously (Brion-Meisels \& Brion-Meisels, 2012; Cabedo-Mas, 2015; Exton \& Enloe, 2015; Tarman, 2018; Yigit, 2017). Every components of society should mutually respect and by respecting and understanding each other only then peace can be achieved. 
The Feasibility of Peace Education. Apart from that, a study done by Al-Smadi, AbuQudais and Mahasneh (2010) tried to promote Peace Education in Jordanian higher education. The main goal of the study is to explore the degree to which the Hashemite University academic administrators promote peace education by inculcating local and global values and norms of students. The degree of promoting peace education is measured by a questionnaire of 32 items distributed in three dimensions: knowledge of peace education, skills of non-violence critical thinking, and behaviors of peace education. It is found that the results indicated that academic administrators contributed to promoting peace education among students in a moderate degree. It also showed that there were no significant differences among peace education dimensions and all the proposed demographics of academic administrators (Al-Smadi et al., 2010).

Interestingly, the elements of Peace Education can be varied not only involving interactions between one and another but rather it can vary to other means of instilling peace values such as through art and expression. A study done by Cabedo-Mas, (2015) revealed that music can be a tool to contribute in building Peace Education. The study aims to review major concerns of Peace Education in relation to music in schools and to encourage teachers to promote musical practices aimed at transforming societies. The author also intended to offer examples of different projects that has made use of music education to contribute to peacebuilding. Peace includes overcoming, reducing, managing and avoiding any kind of violence, direct, cultural or structural (Cabedo-Mas, 2015). The author then proposed the idea that music creates automatic peace itself. He argued that in many cultures, the popular knowledge reinforces the ability to reduce violence in certain situations and music can serve a purpose beyond education alone to serve the community and foster belonging, social inclusion, identity and improve peaceful co-existence in and beyond the classroom. Music also can become a vehicle to connect people and enhance peace. Music education should make the effort to turn presentational musical practices into participatory practices that lead students to share active music making (Cabedo-Mas, 2015).

On the other hand, another study tried to examine how peace education can provide appropriate strategy for sustainable security and development of a country. Mojekeh (2014) outlines major areas of concern for establishing and maintaining human security. The author discussed what the role of teachers in addressing peace issues and the challenges of the education system in Nigeria. Among some of the suggestions mentioned are; the government of Nigeria should enhance the quality of education by expanding access to education, enrollment, and reduction in education wastage. The role of Peace Education must be activated by the government, awareness strategies to be adopted and proper strategies for coordinating and collaborating all the initiators of peace education to be enhanced. Teaching profession must be seen as a vital tool for national development and lastly professional code of ethics must be enforced (Mojekeh, 2014).

\section{Theoretical Framework}

This study takes Danesh's theory of peace education as its theoretical framework. Danesh, $(2008,2011)$ discussed the concept of peace education that enabled students or participants to develop the necessary knowledge, capacity, courage, and skills to create violence-free and peaceful environments in their schools and community. The main objective of Danesh's model of peace education is to focus on education that empower the women, enlighten the boys and men that not to resort to violence or abusing power which is typically accustom to them when been given authority and position. He stated that not only to prepare the future leaders to become peace makers in the society but to have them as the agent for peace in their society. 
Danesh later introduced a concept called unity-based peace education in extending the means of how peace can be achieved not only through conflict resolution but through a new worldview named Integrative Theory of Peace (ITP). He asserted that the concept of unity and not conflict serves as the central governing law of life and once unity is formed, conflicts are often prevented or easily resolved. He coined it as a unity-based worldview. Peace is an outcome from cognitive (knowing), emotive (loving), and conative (choosing) capabilities which helps shape the nature of our worldview. Thus, by having ITP and peace education, students can have a comprehensive program that helps at intrapersonal, interpersonal, intergroup, international, and global areas of human life.

\section{Methods}

In this study, the authors tried to explore the needs and perception of educational leaders in introducing Peace Education as a subject in three primary schools located in Putrajaya, Shah Alam and Klang. It is intended to understand the crucial components that should be inculcated in the curriculum so much so that Peace Education can be seen as a relevant subject to be taught in schools. Peace Education that focuses on creating a sustainable environment to enable citizens to live side by side with each other regardless of political background, ideologies, religious beliefs and practices is needed in a multi-cultural society like Malaysia. Peace Education also ensures the stability of a nation towards building its better future to develop as an exemplary nation that celebrates differences and diversity. Thus, the authors believe that it is needed to inculcate Peace Education from the basic level in education, starting from primary school as a starting point to bring prosperity to the nation. Therefore, the objectives of the study are to:

1. Explore school educational leaders' perception on how Peace Education could be included in the curriculum;

2. Examine the needs for introducing Peace Education in school setting;

3. Describe the challenges that will be faced by the educational leaders in introducing the curriculum at school level.

Based on these three objectives, three research questions have been drawn out;

1. What are the educational leaders' perceptions on Peace Education?

2. What are the educational leaders' perceptions about the implementation of Peace Education as a subject in the classroom?

3. What are the barriers or obstacles for the teachers and/or school leaders to introduce Peace Education as a subject?

This study employs a qualitative design with case study method that is concerned with the perception of educational leaders toward peace education in school setting. This method was selected due to the nature of the study, whereby it offers exploration of the problem or issues that need to be studied (Creswell, 2007). Besides that, by employing a qualitative design, it also provides a complex, detailed understanding of an issue. In fact, qualitative design also helps us to study a group or population, identify variables that can be measured, or hear silenced voices. These are among good explanation to explore a problem rather than to use predetermined information from the literature or results from other research (Creswell, 2007). In addition, this study carefully examined educational leaders' perception and their experience by conducting direct face to face interview and were not influenced or determined by other variables (Bryman, 2008). Furthermore, the reasons for using case study in this research was to cover background conditions related to the phenomenon of study (Yin, 2009).

\section{Participants and Sampling}


In this research, theoretical sampling method has been used and three respondents were selected from three different schools in Selangor, Malaysia. Respondents for the study were voluntary with consent given from their head teachers. All of them were recruited from three separate schools which is located at Putrajaya, Shah Alam and in Klang district in Selangor. One of the three is a 5th grade teacher who is also a head teacher, another is a third grade teacher and the third is a special education officer that is in charge of creating and supervising curriculum for the special needs pupils. All of the respondents work as a school leader who are also teaching.

The three school leaders have met the criteria of; have long-period of time serving in the teaching profession, influential in school's policy and decision making, involved actively in school activities that addressed the needs for the students' development and have credibility among policy makers. Due to these reasons, the respondents volunteered were at least 30 years of age and above. All three were Malay males. Educational leaders are defined as operator or any person who are involved directly with planning, monitoring, maintaining and establishing a school institution.

The selection of the respondents was based on the theoretical sampling where they were chosen on the basis of their representation of important theoretical constructs (Brikci \& Green, 2007; Patton, 1990). Sandelowski (1995) describe the sampling process used is based on emerging theoretical concepts. This sampling approach has the goal of developing a rich understanding of the dimensions of a concept across a range of settings and conditions.

In addition, this method is suitable when the nature of the research focuses on theory and concept development and it corresponds with the theory and concepts that are connected to, grounded in or emergent from real life events and circumstances (Cohen \& Crabtree, 2006). Data gathered from the interview were transcribed and analysed using thematic analysis following Braun and Clarke (2006).

\section{Data Collection}

In order to comply with the code of conduct of doing a research, the researchers had ensured the practice has met ethical standards in carrying out the study. Several ethical issues were addressed such as obtaining the permission from each school, anonymity of each respondents' identity and voluntary participation. Next, the following plan was implemented to obtain data from the respondents. First, a letter asking for permission to cooperate was sent. There were some initial phone conversation happened between the researchers and the respondents in order to setup the date and place for the interview session. A semi-structured interview technique was employed. The interview session was conducted with all the participants at their school compound. This technique allows the interviewee to respond in the most convenient way (Baxter \& Jack, 2008; Brikci \& Green, 2007). Respondents were reportedly feeling comfortable along the session. All sessions were conducted using Bahasa Malaysia as the respondents were more comfortable and confident to communicate with, thus providing more accurate responses.

According to Patton (2002) the focus of this type of interview is on gaining an understanding based on textual information obtained. The nature of questioning involves flexibility but has a set of questions that is prepared earlier by the interviewer prior from the process of the sessions. Furthermore, during the process of interview, the interviewer has used various probing strategy in order to get more details from their answers. Sometimes, the interviewees were asked to expand more about their statements and answers for the researchers 
to get the actual meaning and detail or any additional perspectives that can be told from their perspectives.

Interviews. The interview featured semi-structured and standardized open-ended questions; each teacher took part in an hour interview. According to Baxter and Jack (2010), open-ended interviews in carrying out case study especially focusing on small sample is one of the efficient way to collect in-depth exploration as compared to surveys. This can be seen in the excellent works of some other qualitative researchers (Kratt, 2018; Peña, Jones, Orange, Simieou, \& Márquez, 2018).

Field notes. Multiple set of field notes have been used in collecting details of the context in this study as well as respondents' interaction while having the conversation with them. This is to ensure rigor and rich details of the present study and provides clearer descriptions of each responses to the questions (Maher, Hadfield, Hutchings, \& Eyto, 2018).

Document analysis. A series of collection of old syllabus book dated around 70 s named 'Tata Rakyat' (Civic Conduct) was examined. This book serves as a means to educate pupils at primary level on the importance of peace at various stages. It also aids as a valuable insight that adds additional knowledge base prior to the present study (Bowen, 2009).

\section{Data Analysis}

Data obtained from the interview sessions were analysed using thematic analysis (Braun $\&$ Clarke, 2006). Themes and patterns were extracted, analysed and reported manually by the researchers. Based on the analysis of the feedback of interviews, the researchers identified some emergent themes namely; (1) Challenges and obstacles of introducing peace education as a new curriculum to the school leaders as well as for teachers (2) Definitions regarding the concept of peace education (3) The needs of implementing peace education (4) The importance of peace education and benefits of introducing peace education in schools institution. Themes emerged after the analyses of the definitions provided by the participants are presented below in a frequency based sequence. Participating teachers defined the concept of peace in relation with the following words; character building, preserving peace, stability, knowing history, peace appreciation, peace keeping and patriotism.

\section{Validity}

The present study used multiple sources of data collection from interviews of respondents, field notes and document analysis. This is to ensure the validity of the study and to establish accuracy and consistency of the data obtained in the study (Creswell, 2007; Patton, 1990; Yin, 2009). Later, triangulation was made between interviews, field notes and document analysis was able to show the densities of the respondents' understanding of the topic, while at the same time remove the researchers' prejudices (Bryman, 2008; McAlister et al., 2018; Richards, 2009). The credibility of the research has been obtained by using member checking method and prolong engagement with the respondents (Maher et al., 2018). This was done by showing back all the transcription interviews and all of the respondents acknowledged the transcripts. The researchers also have established reliability by administering expert verification technique by using other researcher in reviewing coding and themes generated and calculated the inter-rater score. It is found that the score achieved more than $80 \%$ of agreement and it has successfully decrease biases during the process of analysis.

\section{Findings}

Feedback from the interview sessions gave the impression of the need to introduce peace education in school both at primary and secondary level. Findings shows that all school leaders' 
shared a common belief that it was important to know, maintain and preserve what was peace and peace education. Furthermore, they all understood the need for advocating this kind of program or subject within the Malaysian and educational systems since there have been a lot of issues regarding disharmony, disrespects among Malaysian students.

However, although they all agreed that there was a need for introducing peace education in the curriculum it was also challenging for them to implement it at the school level. This means, they perceived and predicted as teachers, they needed to perform various tasks and undergo special kind of training regarding peace education before they can teach the students. However, all of them showed their willingness to go for such an experience in order to bring a better education to the generation. Finally, they brought up the issues again about the importance of peace education and its benefits to introduce in school both in primary and secondary levels.

\section{Knowledge about Peace Education}

In response to Question 1, three out of three school leaders reported that they never heard anything about peace education in their entire career as a school leaders and teachers. Teacher $\mathrm{X}$ said that:

"Never heard before." (Teacher X/DU2) which means he never heard about it before. Another two respondents also acknowledged that they also never heard about the term of peace education before.

"Never heard it, this is my first time hearing it..." (Teacher Y/DU2) and another respondents said almost the same:

"Err... I never came across this term. Usually it's about other types of education. This

is my first time hearing this term." (Teacher Z/DU2).

Having the knowledge about peace education, the researchers infer that all of the respondents were considered new to this kind of information since peace education is a new term in the field of education. One respondent claimed that it was a new thing to him since no one had ever come out with the term of peace education.

\section{Peace education as a pre-cursor to harmony}

In response to question number two, there were dissimilarities in defining what peace education is all about. Two out of three school leaders mentioned it is about formation of characters and introducing positive values for our multiracial country.

This can be seen in:

"The establishment of school culture, inculcation of values among the students towards a more peaceable life that serves as the foundation of a multicultural society..." (Teacher X/DU5).

This statement is similar to interviewee two where he said:

"Peace education is more towards respecting each other between the races which is similar to what the Malaysian constitution has set..." (Teacher Y/DU 5).

Meanwhile a different response came from respondent number three where he mentioned that: "...it is to uphold unity and prepare us if something like war is happening upon us." (Teacher Z/DU5).

The Importance of Peace Education. Next, for question number three, all school leaders agreed that it is very important to introduce Peace Education in the curriculum. For instance, one respondent stated that in order to maintain the harmony in this country which consists of multi-racial components of society Peace Education is the possible solution. He stated that: 
“...peace value is crucial to be practiced so we will prosper with harmony...” (Teacher $\mathrm{X} / \mathrm{DU} 7)$.

Furthermore, this point is related to the next respondent where he added the importance bringing the awareness about the security level of Malaysia which is not always in peaceful state. Therefore we (citizen) must maintain it by introducing peace education. He mentioned that

"....it is very important since we used to believe that we are always in peaceful condition, thus ignoring the effort of maintaining it..." (Teacher Z/DU6).

The needs for implementing peace education.

As for question five, two from three school leaders agreed that Malaysia has the need to introduce peace education as a subject with concern for implementation, costs and teacher training as per previous question. This can be seen when both stated that:

"...I surely agreed that Peace Education should be introduced..." (Teacher Y/DU19).

Another participant also reported the same:

“...I strongly agree that Peace Education should be introduced in Malaysia) ...” (Teacher $\mathrm{X} / \mathrm{DU} 16)$.

However, another respondent reported differently when he mentioned that he did not agree that Peace Education should be introduced as a core subject but rather enough if we make it as an elective subject that can be thought within five to ten minutes.

"It is better be instilled in their heart rather as as subject per se. Instead we can prepare it as an elective subject that we can teach around five to ten minutes..." (Teacher Z/DU13).

Additionally, one respondent added that Malaysia has the need to introduce Peace Education as a subject with concern for preserving peace and stability in the society.

He said:

“...because students need to be told how important to keep and maintain the peace since Malaysia now has long in the state of peace thus maybe this new generation has forgotten how precious is this blessing..." (Teacher Y/DU19).

The challenges of peace education.

Last but not least, for the final question, one out of three school leaders described the importance of knowledge about peace education among teachers as a precursor in order to introduce peace education. It is also supported by the other respondents who reportedly shared the same opinion as he mentioned lack of expertise and lack of interest among students as challenges to introduce peace education. This can be seen when they argued that:

"... any subjects that we want to introduce will require knowledge on the subject

per se before we introduce it...” (Teacher X/DU19).

"...we cannot make it as a new subject since it will require more efforts such as new books, new training and new examination where we are already have a lot of subjects in our school) ..." (Teacher Z/DU13).

On the other hand, another school leader brought the issue of the challenges in implementation of the subject as new troubles for the educators. He said:

"...yes, indeed it will be a burden to us for a new additional subject to be introduced..." (Teacher Y/DU27).

\section{Discussion}

\section{The Need for Peace Education}


In the present study, it is found that there was a dire need of introducing Peace Education in the Malaysian educational system. This can be seen when all of the respondents agreed to the idea of introducing this subject will better the condition of the students especially in minimizing violence, racial conflicts and racism within school society in general. However, they reported unanimously that there will be challenges in terms of implementation of the subject in the curriculum. Besides, all the respondents agreed that if peace education is introduced, a more peaceful society will emerge.

Furthermore, the present study also successfully indicated to us that the educational leaders have stated that Peace Education as an important subjects or curriculum that should be introduced in the educational system. They added that in order to materialize this, it is very important to include teachers as the first agent in transferring the knowledge to the students in order to introduce Peace Education. This finding is concurrent with a study conducted by DemIr (2011) where the researchers found that the teachers had the most important role in introducing Peace Education. In fact, in terms of perceptions, all the respondents stated a similar definition on global, national and individual definition of peace. In other words, they did not have different understanding of conceptualizing Peace Education and the importance of implementing it.

On the other hand, the present study also found that when discussing about the elements of Peace Education, the emerging theme behind the concept of peace has prevailed. This can be seen when respondents highlighted the importance of Peace Education as a pre-cursor to harmony and in order to uphold the values of peace, one must adhere to the values of multiracial interactions in this country such as tolerant and respecting each other which will foster the formation of good characters among citizens. Similarly, the study done by Demir (2011) found that the elements of peace such as democratic, tolerant, respecting differences and fairness were among the good characteristic and pre-cursor towards establishing good and harmonious society.

\section{Peace Pedagogy Framework and Integrative Theory of Peace}

The present study shows the challenges that will be faced by the educational leaders in order to introduce Peace Education in the curriculum. It starts from educating the teachers, providing appropriate materials and resources, conducting trainings as well as designing and creating reading materials for the students that will incur a lot of cost. However, it should not be considered as the obstacles to introduce a program or syllabus that will benefit the whole generation. In fact, it can be minimized into a more cost-effective planning that utilises whatever resources that we already have. For instance, peace elements of being tolerant with others can be effectively practiced by the teachers and staff in showing the best examples to the students. It can also be manifested through a campaign that addresses the issue of multi-racial that can be learned within the school community. An excellent example from a work by (Exton \& Enloe, 2015) where they emphasized how important it was for young generation being educated about peace education. They categorized the effort into three stages of Peace Education which were peacekeeping, peace-making and peacebuilding. To implement learning based on a culture of peace by utilising any activities that foster peace keeping and peace learning. They have suggested that peace also has its taxonomy of scope namely global peace education, conflict resolution programs, violence prevention programs, development education and nonviolence education.

The theory came from Danesh (2011) where he brought the new concept of Unity-Based Peace Education (UBPE) in 112 schools in Bosnia and Herzegovina indicated that the program has succeeded in bringing the concept of unity as a central theme in unifying the school community and introduced peace as part of their curriculum. It is called the Education for Peace 
Integrative Curriculum where it consists of ten interrelated books that comprise of a comprehensive peace education curriculum. It covers several core subjects such as literature, history, math, biology, etc as peace education is embedded inside of each lesson. Through this curriculum teachers will become familiar with the principles of peace and will be able to integrate these principles into their daily lesson and activities with their students. Meanwhile, for the case of Malaysia, among of the ways that can effectively introduce Peace Education element is by expanding what Danesh's work on the concept of UBPE where public schools can adopt such principles and framework of violence prevention programs that can help in addressing the issues of unity-integration perspective taking, multi-racial discrimination and combating bullying problems. However this is yet to be seen in the previous work (Abd Kadir et al., 2014; Askandar, 2006; Shamsul, 2015; Shamsul \& Anis, 2011; Rea et al., 2018). In addition to that, to instil Peace Education program in public schools namely like peer mediation programs which is to teach effective methods and principles of assisting peers in resolving conflicts themselves, thus taking on significant peacebuilding and peace-making roles (Samuel, 2018). The practice of promoting caring and kindness within school environment also considered to be important for the same role and method.

\section{Implications and conclusion}

Themes emerged from interview sessions described a clear understanding on the level of knowledge about Peace education among the school leaders. This has answered research question one where we would like to know what the perception on Peace Education were. In comparison with several studies (Nassif, 2016; Oueijan \& Tannous 2011) where they explored some of the Lebanon's school principal on the viability to introduce Peace Education in their school. They discovered that Peace Education and peace program was feasible in their country but at the same time they also realized that many challenges would form obstacles throughout the process. In addition to that they also reported that due to religious and political intervention in their educational system, it seemed rather difficult to manoeuvre for change. Among the factors were due to demographic redistribution that was carried out to serve political interest that made two major ethnic and religion which are Muslims and Christian clashes thus made the conflict more likely to occur. Another lesson that can be learned is that they reported that it seemed to be mutually agreed among the school principals that positive change was possible in their educational system. Some school principals stated that real peace started from within, and so it does real change. This is similar with the present study where all respondents reported that Peace Education is workable and change should be made in order to better the society at large regardless of what country you live in. In other multicultural countries school is one of the best institutions to instil peace values and principles. Different kind of races permit the interaction and therefore minimize prejudice and stereotypes. Educational leaders in developed countries can learn that Peace Education is a workable solution and it invites real change from the topdown approach level of management.

Furthermore, this study can serve as an indicator about the need to introduce Peace Education as a subject in the schools' curriculum in any country that possess the same characteristic of Malaysia; multi-religion, multi-races and diverse language. However, the implementation on how it should be introduced is what policy makers and other stakeholders should take into consideration before making it as national curriculum. This is crucial before any kind of policy is being introduced in the national school system where it will involve a lot of students' capacity to understand and apply their understanding of the subject in their life.

To introduce any policy changes in the system requires a careful, analytical and systematic ways of analysing the new policy that is intended to be introduced before implementing it in the state or national level. As a result, the present study is crucial for 
researchers, policy makers and other stakeholders to use as a tool before deciding to introduce Peace Education in the system. Furthermore, this study has helped us to examine more and get a clearer picture on what are the challenges that will be faced by teachers in the $21^{\text {st }}$ century era if Peace Education is to be introduced. It also helps us to discover if there really is a need for this new curriculum to be included in the system.

For future research, some improvements can be used for a broader scope of the study if it is to be conducted to see its relevance in other level of school programs such as secondary in tertiary level namely:

(1) Measuring awareness about importance of Peace Education by constructing questionnaire to survey its needs for any particular type of schools and area. For instance, area that has higher percentage of multi-racial community can be examined first and questionnaire can be distributed in this area.

(2) Studying only the teachers will offer only one sided perspective but inclusion of potential students who will learn about the Peace Education can provide clearer justification on how it should be taught.

(3) Needs analysis can be carried out first in order to determine the suitability of the selected school before introducing Peace Education as part of the curriculum.

\section{Acknowledgements}

This research was supported by grants from the IIUM Research Initiative Grant Scheme which is provided by the Ministry of Education Malaysia.

\section{References}

Abd Kadir, N., Haneem, F., \& Ismail, J. (2014, March). Peace Education : Inculcating Global Peace Values Among Students Through Literary Texts in Malaysia. Paper presented at the $2^{\text {nd }}$ Global Summit on Education. Kuala Lumpur: WorldConferences.net. Retrieved from http://worldconferences.net/proceedings/gse2014/

Al-Smadi, R. T., AbuQudais, M., \& Mahasneh, R. A. (2010). Academic administrators making a difference: promoting peace education in jordanian higher education. International Journal of Applied Educational Studies, 9(1), 67-78. Retrieved from http://www.ijaes.com

Askandar, K. (2006). Budaya perdamaian budaya kita. Penang: Research and Education for Peace, USM.

Baxter, P., \& Jack, S. (2008). Qualitative Case Study Methodology : Study Design and Implementation for Novice Researchers. The Qualitative Report, 13(4), 544-559.

Braun, V., \& Clarke, V. (2006). Using Thematic Analysis in Psychology. Qualitative Research in Psychology, 3(2), 77-101. doi:10.1191/1478088706qp063oa

Brikci, N., \& Green, J. (2007). A Guide to Using Qualitative Research Methodology. Medicins Sans Frontieres, 1-30. Retrieved from http://hdl.handle.net/10144/84230

Brion-Meisels, L., \& Brion-Meisels, S. (2012). Peace Education across Cultures : Applications of the Peaceable Schools Framework in the West Bank. Journal of Peace Research, 37(4), 572-600. doi:10.1111/j.1468-0130.2012.00771.x

Brock-Utne, B. (2009). A gender perspective on peace education and the work for peace. International Review of Education, 55(2-3), 205-220. doi:10.1007/s11159-008-9122-z

Bryman, A. (2008). Social Research Methods (3rd Editio). New York: Oxford University Press Inc. 
Bowen, G. A. (2009). Document Analysis as a Qualitative Research Method. Qualitative Research Journal, 9(2), 27-40. doi:10.1016/j.clay.2016.12.009

Cabedo-Mas, A. (2015). Challenge and perspectives of Peace Education in Schools: The Role of Music. Australian Journal of Music Education, 1, 75-85. Retrieved from https://search.informit.com.au/documentSummary; $\mathrm{dn}=599874007102222 ; \mathrm{res}=$ IELHSS

Cohen, D., \& Crabtree, B. (2006, July). Qualitative Research Guidelines Project. Robert Wood Johnson Foundation. Retrieved from http://www.qualres.org/HomeCase3591.html

Creswell, J. W. (2007). Qualitative Inquiry \& Research Design; Choosing Among Five Approaches (2nd ed.). California: Sage Publications, Inc.

Danesh, H. B. (2008). The Education for Peace integrative curriculum: concepts, contents and efficacy. Journal of Peace Education, 5(2), 157-173. doi:10.1080/17400200802264396

Danesh, H. B. (2011). Education For Peace Reader. Victoria, Canada: EFP Press.

Demir, S. (2011). An Overview of Peace Education in Turkey : Definitions, Difficulties , and Suggestions : A Qualitative Analysis. Educational Sciences: Theory \& Practice, 11(4), 1739-1746. Retrieved from http://oldsite.estp.com.tr/

El-Muhammady, A. (2016, November). The Perfect Target - Youth And Radicalization. Keynote address at the International Conference on Education Towards Global Peace. Kuala Lumpur, International Islamic University Malaysia.

El-Muhammady, A. (2018, October 12). Humanizing A Terrorist. Retrieved from http://www.asia-pacific.undp.org/content/rbap/en/home/blog/2018/humanizing-aterrorist--for-extremist-rehabilitator-ahmad-el-muh.html

Exton, M., \& Enloe, W. (2015). Lessons from Hiroshima : building cultures of peace in international education. International Schools Journal, XXXIV(1), 20-27. doi: 10.1111/j.1365-263X.2007.00857.x

Khairi, A. (2016). Peace-building in Malaysia : Study on the National Unity and Integration Department (DNUI) Programmes. Jurnal Sultan Alauddin Sulaiman Shah, 3(2), 92-105. Retrieved from http://journal.kuis.edu.my/jsass/

Kratt, D. (2018). Teachers' perspectives on educator mental health competencies : A qualitative case study. American Journal of Qualitative Research, 2(1), 22-40.

Lafer, S., \& Tarman, B. (2019). Editorial 2019: (2)1, Special Issue. Journal of Culture and Values in Education, 2(1), i-v. Retrieved from http://cultureandvalues.org/index.php/JCV/article/view/34

Lamanauskas, V. (2015, February). Peace Pedagogy or/and Education for Peace: Some Actualities. Problems of Education in The 21st Century (Vol. 63). Lithuania: University of Šiauliai.

Maher, C., Hadfield, M., Hutchings, M., \& Eyto, A. De. (2018). Ensuring Rigor in Qualitative Data Analysis : A Design Research Approach to Coding Combining NVivo With Traditional Material Methods. International Journal of Qualitative Methods, 17, 1-13. doi:10.1177/1609406918786362

McAlister, A., Lee, D., Ehlert, K., Kajfez, R., Faber, C., \& Kennedy, M. (2018). Qualitative Coding: An Approach to Assess Inter-Rater Reliability. American Society for Engineering Education. doi:10.18260/1-2--28777 
Miller, L., M. (2018). Social Networking Strategy for Creating Public Value in Eastern India. Journal of Ethnic and Cultural Studies, 5(1), 85-93.

Ministry of Education. (2013). Malaysia Education Blueprint 2013 - 2025. Education (Vol. 27). doi:10.1016/j.tate.2010.08.007

Mojekeh, M. O. (2014). Peace Education For Sustinable Security and Development : Envisioning the Way Forward. Intellectbase International Consortium, 7(23), 40-50.

Mustafa, M. (2017, January 28). The young Malaysian Terrorist: A profile. Free Malaysia Today.

Nassif, N. (2016). Building a Peace Culture : Peace Education Possibilities in Schools in Lebanon A Qualitative Study. (Doctoral dissertation). Available from ProQuest Dissertations and Theses database. (UMI No. 10181181)

Oueijan, H. N., \& Tannous, J. M. (2011). A National Peace Education Program in Lebanon: Exploring the Possibilities from the Leaders' Perspectives (Doctoral dissertation). Available from ProQuest Dissertations and Theses database. (UMI No. 3475190)

Patton, M. (1990). Qualitative Evaluation and Research Methods. (pp. 169-186). Beverly Hills, CA: Sage.

Patton, M. (2002). Qualitative research \& evaluation methods (3rd ed.). Thousand Oaks, CA: Sage.

Peña, C., Jones, L., Orange, A., Simieou, F., \& Márquez, J. (2018). Academic success and resiliency factors : A case study of unaccompanied immigrant children. American Journal of Qualitative Research, 2(1), 162-181.

Raza, K. (2018). The Muddy Waters of Multicultural Acceptance: A Qualitative Case Stuon Antisemitism and the Israeli/Palestinian Conflict. Journal of Ethnic and Cultural Studies, 5(1), 1-15.

Rea, D. C., Carter, C. F., Parfitt, C. M., Wilkerson, J. R., \& Valesky, T. C. (2017). Using Dispositional Surveys to Improve Individual and Program Quality in Educational Leadership. Journal of Ethnic and Cultural Studies, 4(2), 81-87.

Richards, L. (2009). Handling Qualitative Data. London: Sage Publications Ltd.

Samuel, T. K. (2018). Undergraduate Radicalisation in Selected Countries in Southeast Asia: A Comparative Quantitative Analysis on the Perception of Terrorism and CounterTerrorism among Undergradutes in Indonesia, Malaysia, the Philipines, Singapore and Thailand. Kuala Lumpur, Malaysia: The Southeast Asia Regional Centre for CounterTerrorism

Sandelowski, M. (1995). Sample size in qualitative research. Research in Nursing \& Health, 18(2), 179-183. doi:10.1002/nur.4770180211

Shamsul, A. B. (2015). Conceptualizing Diversity: Towards Managing Political and Religious Differences in Malaysia.

Shamsul, A. B., \& Anis, Y. . (2011). Managing Peace in Malaysia: A case study. UKM Ethnic Studies Paper, 18(18), 1-16.

Tarman, B., \& K1lınç, E. (2018). Poetry in the Social Studies Textbooks in Turkey. Journal of Culture and Values in Education, 1(1), 50-62. Retrieved from

http://cultureandvalues.org/index.php/JCV/article/view/4

Tarman, B. (2018). The Awareness of Social Studies Teacher Candidates' Regarding Special 
Area Competencies and the Overlap Level of These Competencies with Social Studies Degree, Journal of Ethnic and Cultural Studies, 5 (2), 16-28.

United Nations Educational, Scientific, and Cultural Organization. (2014, November). Basic Texts: Including texts and amendments adopted by the General Conference at its 37th session. Retrieved from the United Nations Educational, Scientific, and Cultural Organization website: https://unesdoc.unesco.org/ark:/48223/pf0000226924

United Nations, General Assembly, (6 October 1999). Declaration and Programme of Action on a Culture of Peace, A/53/243, Retrieved from https://undocs.org/A/RES/53/243

Yigit, M. (2017). Value Priorities of Public and Private University Students. Research in Social Sciences and Technology, 2(1). 1-17. Retrieved from http://ressat.org/index.php/ressat/article/view/38

Yin, R. K. (2009). How to Do Better Case Studies. In D. J. Bickman, Leonard \& Rog (Ed.), The Sage Handbook of Applied Social Research Methods (2nd ed., pp. 254-282). California: Sage Publications, Inc.

Zolkepli, F., \& Tan, R. (2018, July 28). Extremist Ideologies at Institutions Worrying. The Star Online. Retrieved from https://www.thestar.com.my/news/nation/2018/07/28/extremist-ideologies-atinstitutions-worrying/

Manuscript received March, 20, 2019 Revision received April, 21, May 05, 2019 Accepted May 14, 2019 